\title{
ANALISIS REGRESI SPASIAL DURBIN UNTUK MENGANALISIS FAKTOR-FAKTOR YANG BERHUBUNGAN DENGAN PERSENTASE PENDUDUK MISKIN
}

\author{
Yulita Putri Lokang ${ }^{1}$, Ignatius Aris Dwiatmoko \\ Alumni Universitas Sanata Dharma ${ }^{1}$, Dosen Universitas Sanata Dharma ${ }^{2}$ \\ Jalan Paingan, Maguwoharjo, Depok, Sleman, Daerah Istimewa Yogyakarta \\ Sur-el : putrilokang@gmail.com ${ }^{1}$, aris.dwiatmoko@usd.ac.id ${ }^{2}$
}

\begin{abstract}
The percentage of poor people is the percentage of the population who have a monthly per capita expenditure below the poverty line. In this study, spatial Durbin regression used to know the factors which is giving effect to the percentage of poor population with maximum likelihood method to estimate parameters. This method used because it can maximize the probability of occurrence of each parameter. From 6 independent variables that are thought to be related to the percentage of poor people, there are only 4 independent variables that can be modeled by the spatial Durbin regression model because of the presence of significant spatial autocorrelation based on the Moran Index test. That are school participation rates aged 16-18 years, inflation, life expectancy at birth, and the human development index. The measure of the goodness of the Durbin spatial regression model calculated by looking for the value of $R^{2}$ is $68.4 \%$.
\end{abstract}

Keywords: percentage of poor people, spasial Durbin regression, maximum likelihood method, Moran index test

\begin{abstract}
Abstrak : Persentase penduduk miskin adalah persentase penduduk yang memiliki pengeluaran per kapita bulanan di bawah garis kemiskinan. Dalam penelitian ini, regresi spasial Durbin digunakan untuk mengetahui faktor-faktor yang berpengaruh pada persentase penduduk miskin dengan metode kemungkinan maksimum untuk mengestimasi parameternya. Metode ini digunakan karena dapat memaksimalkan probabilitas kejadian dari masing-masing parameter yang diduga. [1] Dari 6 variabel independen yang dianggap berhubungan dengan persentase penduduk miskin, hanya ada 4 variabel independen yang dapat dimodelkan oleh model regresi spasial Durbin karena adanya autokorelasi spasial yang signifikan berdasarkan uji Indeks Moran. Variabel tersebut adalah angka partisipasi sekolah usia 16-18 tahun, inflasi, usia harapan hidup saat lahir, dan indeks pembangunan manusia Ukuran kebaikan model regresi spasial Durbin yang terbentuk dihitung dengan mencari nilai $\boldsymbol{R}^{2}$ adalah $\mathbf{6 8}, \mathbf{4} \%$.
\end{abstract}

Kata kunci: persentase penduduk miskin, regresi spasial Durbin, metode kemungkinan maksimum, uji indeks Moran

\section{PENDAHULUAN}

Analisis regresi adalah metode yang digunakan untuk mengukur besarnya pengaruh variabel independen terhadap variabel dependen dan memprediksi variabel dependen dengan menggunakan variabel independen. [2]. Salah satu jenis analisis regresi adalah analisis regresi spasial. Dasar pemikiran analisis ini adalah hukum pertama tentang geografi yang dikemukakan oleh W. Tobler, yaitu: "Everything is related to everything else, but near thing are more related than distant thing", yang berarti : segala sesuatu saling berhubungan satu dengan yang lainnya, tetapi sesuatu yang dekat lebih mempunyai pengaruh daripada sesuatu yang jauh. [3]. Pada analisis regresi spasial, pengaruh kedekatan daerah hanya diperhitungkan pada variabel dependennya .Pada kenyataannya, pengaruh kedekatan daerah dapat 
terjadi pada variabel dependen maupun variabel independen. Jenis analisis regresi spasial yang memperhatikan pengaruh kedekatan daerah pada variabel dependen maupun variabel independen adalah analisis regresi spasial Durbin. Analisis Regresi Spasial Durbin dilakukan dengan mengestimasi parameter-parameter yang dibutuhkan dalam model regresi spasial Durbin, yaitu parameter $\rho$ dan $\beta$. Dalam penelitian ini, estimasi parameter dilakukan dengan menggunakan metode kemungkinan maksimum.

Banyak sekali penerapan analisis regresi spasial Durbin, salah satunya dalam bidang ekonomi. Permasalahan ekonomi yang masih menjadi persoalan cukup besar di Indonesia adalah tingginya persentase penduduk miskin. Berdasarkan data Badan Pusat Statistik (BPS) pada bulan Maret 2018, Jawa Tengah merupakan provinsi dengan persentase penduduk miskin terbesar kedua di pulau Jawa, yaitu jumlah penduduk miskin yang mencapai 3,9 juta orang dengan tingkat kemiskinan yang cukup besar yaitu 11,32\%.[4]. Beberapa faktor yang berhubungan dengan persentase penduduk miskin adalah angka partisipasi sekolah, tingkat partisipasi angkatan kerja, inflasi, rata-rata lama sekolah, usia harapan hidup, dan indeks pembangunan manusia. Dalam penelitian yang dilakukan oleh Aldino (2018) dengan metode regresi data panel dengan menggunakan data dari BPS Jawa Tengah pada tahun 2011-2016 diperoleh hasil bahwa faktor-faktor yang berpengaruh signifikan terhadap persentase penduduk miskin di Jawa Tengah adalah indeks pembangunan manusia dan jumlah penduduk.[5].
Penelitian lain yang berjudul "Analisis Regresi Spasial pada Data Jumlah Penduduk Miskin Provinsi Lampung pada Tahun 2017", [6], dalam penelitian tersebut diperoleh kesimpulan bahwa model regresi spasial lebih baik daripada model regresi linear berganda dalam menganalisis data penelitian yang digunakan. Hal ini menunjukkan bahwa pengaruh spasial perlu diperhatikan juga dalam menganalisis data karena hubungan ketetanggaan antar daerah yang satu dengan daerah yang lain dapat membuat model yang terbentuk menjadi lebih baik.

Penelitian lain yang berkaitan dengan regresi spasial Durbin dengan judul analisis kemiskinan dengan pendekatan model regresi spasial Durbin (studi kasus: Kabupaten Gianyar) dengan kesimpulan tidak ada lag variabel independen dengan pembobot yang signifikan menyebabkan hasil estimasi parameter menggunakan model spasial Durbin menjadi tidak signifikan. [7].

Dalam penelitian ini, data yang digunakan adalah data tahun 2017 dari 35 kabupaten/kota di provinsi Jawa Tengah. Tujuan dari penelitian ini adalah untuk mengetahui faktor-faktor apa saja yang berpengaruh signifikan terhadap persentase penduduk miskin di Jawa Tengah dan juga untuk mengetahui seberapa baik model yang terbentuk untuk menjelaskan persentase penduduk miskin di Jawa Tengah.

\section{METODOLOGI PENELITIAN}

\subsection{Langkah Penelitian}

Langkah penelitian yang digunakan adalah: 
1) Mengumpulkan data.

2) Membentuk matriks pembobot spasial.

3) Menguji ada tidaknya autokorelasi spasial pada masing-masing variabel dengan menggunakan uji Indeks Moran.

4) Menentukan variabel-variabel apa saja yang memenuhi syarat untuk pemodelan. Untuk analisis regresi spasial Durbin, variabel yang digunakan adalah variabel yang terdapat autokorelasi spasial.

5) Mengestimasi parameter dengan menggunakan metode kemungkinan maksimum.

6) Membentuk model regresi spasial Durbin

7) Menguji kebaikan model dengan mencari nilai $R^{2}$. $\begin{array}{llr}\text { 8) } & \text { faktor-faktor } \quad \text { yang } \\ \text { berpengaruh } & \text { signifikan } & \text { dengan }\end{array}$ menggunakan uji $t$.

\subsection{Data Penelitian}

Dalam penelitian ini, data yang digunakan adalah data yang berasal dari Badan Pusat Statistik (BPS). Datanya terdiri dari persentase penduduk miskin $(Y)$ sebagai variabel dependen, sedangkan variabel independen terdiri dari: angka partisipasi sekolah usia 16-18 tahun $\left(X_{1}\right)$, tingkat partisipasi angkatan kerja $\left(X_{2}\right)$, inflasi $\left(X_{3}\right)$, rata-rata lama sekolah $\left(X_{4}\right)$, usia harapan hidup saat lahir $\left(X_{5}\right)$, dan indeks pembangunan manusia $\left(X_{6}\right)$. Data Penelitian yang digunakan terdapat pada tabel 1 sebagai berikut

Tabel 1. Data Penelitian yang Digunakan

\begin{tabular}{lccccccc}
\hline \multicolumn{1}{c}{ Nama Kabupaten/Kota } & $\mathbf{Y}$ & $\mathbf{X 1}$ & $\mathbf{X 2}$ & $\mathbf{X 3}$ & $\mathbf{X 4}$ & $\mathbf{X 5}$ & $\mathbf{X 6}$ \\
\hline Kabupaten Brebes & 19.14 & 53.72 & 67.42 & 4.24 & 6.18 & 68.61 & 64.86 \\
Kota Tegal & 8.11 & 70.06 & 66.33 & 4.03 & 8.29 & 74.23 & 73.95 \\
Kabupaten Tegal & 9.9 & 60.68 & 66.41 & 3.58 & 6.55 & 71.14 & 66.44 \\
Kabupaten Banyumas & 17.05 & 67.07 & 65.19 & 3.91 & 7.4 & 73.33 & 70.75 \\
Kabupaten Pemalang & 17.37 & 62.28 & 65.57 & 3.64 & 6.31 & 72.98 & 65.04 \\
Kabupaten Purbalingga & 18.8 & 60.97 & 71.68 & 3.72 & 6.87 & 72.91 & 67.72 \\
Kabupaten Kebumen & 19.6 & 85.01 & 66.84 & 3.25 & 7.29 & 72.98 & 68.29 \\
Kota Pekalongan & 7.47 & 66.08 & 69.28 & 3.61 & 8.56 & 74.19 & 73.77 \\
Kabupaten Pekalongan & 12.61 & 60.76 & 70.98 & 4.01 & 6.73 & 73.46 & 68.4 \\
Kabupaten Banjarnegara & 17.21 & 62.8 & 70.95 & 3.67 & 6.27 & 73.79 & 65.86 \\
Kabupaten Batang & 10.8 & 60.9 & 67.7 & 3.44 & 6.61 & 74.5 & 67.35 \\
Kabupaten Wonosobo & 20.32 & 55.14 & 72.37 & 3.21 & 6.51 & 71.3 & 66.89 \\
Kabupaten Purworejo & 13.81 & 85.24 & 64.48 & 4.29 & 7.69 & 74.26 & 71.31 \\
Kabupaten Kendal & 11.1 & 62.81 & 66.49 & 3.6 & 6.85 & 74.24 & 70.62 \\
Kabupaten Temanggung & 11.46 & 61.18 & 74.37 & 3.12 & 6.9 & 75.42 & 68.34 \\
Kota Magelang & 8.75 & 90.74 & 65.32 & 3.9 & 10.3 & 76.66 & 77.84 \\
Kabupaten Magelang & 12.42 & 70.36 & 74.49 & 3.47 & 7.41 & 73.39 & 68.39 \\
Kota Semarang & 4.62 & 76.12 & 69.87 & 3.64 & 10.5 & 77.21 & 82.01 \\
Kabupaten Semarang & 7.78 & 73.34 & 76.37 & 3.67 & 7.87 & 75.57 & 73.2 \\
Kota Salatiga & 5.07 & 86.86 & 70.53 & 3.5 & 10.15 & 76.98 & 81.68
\end{tabular}




\begin{tabular}{lccccccc}
\hline \multicolumn{1}{c}{ Nama Kabupaten/Kota } & Y & X1 & X2 & X3 & X4 & X5 & X6 \\
\hline Kabupaten Boyolali & 11.96 & 66.69 & 69.96 & 3.08 & 7.44 & 75.72 & 72.64 \\
Kabupaten Klaten & 14.15 & 81.23 & 66.93 & 3.12 & 8.23 & 76.62 & 74.25 \\
\hline Kabupaten Demak & 13.41 & 70.89 & 67.73 & 3.57 & 7.47 & 75.27 & 70.41 \\
Kabupaten Grobogan & 13.27 & 56.5 & 72.15 & 4.05 & 6.66 & 74.46 & 68.87 \\
Kabupaten Sragen & 14.02 & 78.71 & 71.12 & 3.18 & 7.04 & 75.55 & 72.4 \\
Kabupaten Kudus & 7.59 & 70.47 & 71.75 & 4.17 & 8.31 & 76.44 & 73.84 \\
Kabupaten Jepara & 8.12 & 66.33 & 69.85 & 2.83 & 7.33 & 75.68 & 70.79 \\
Kota Surakarta & 10.65 & 81.28 & 66.1 & 3.1 & 10.38 & 77.06 & 80.85 \\
Kabupaten Karanganyar & 12.28 & 79.32 & 70.24 & 3.15 & 8.5 & 77.31 & 75.22 \\
Kabupaten Sukoharjo & 8.75 & 82.48 & 67.29 & 3.4 & 8.71 & 77.49 & 75.56 \\
Kabupaten Wonogiri & 12.9 & 81.61 & 71.22 & 2.32 & 6.68 & 76 & 68.66 \\
Kabupaten Pati & 11.38 & 63.29 & 66.83 & 3.51 & 7.08 & 75.8 & 70.12 \\
Kabupaten Rembang & 18.35 & 68.92 & 70.78 & 3.31 & 6.94 & 74.32 & 68.95 \\
Kabupaten Blora & 13.04 & 67.49 & 70.21 & 2.98 & 6.45 & 73.99 & 67.52 \\
Kabupaten Cilacap & 13.94 & 69.84 & 66.22 & 4.41 & 6.91 & 73.24 & 68.9 \\
\hline Sur & & & & & &
\end{tabular}

Sumber: BPS Provinsi Jawa Tengah (https://jateng.bps.go.id/)

\subsection{Matriks Pembobot Spasial}

Matriks pembobot spasial merupakan matriks yang menyatakan hubungan kedekatan antara daerah yang satu dengan daerah yang lain. Hubungan kedekatan dapat diketahui melalui 2 sumber [7], yaitu:

\section{Ketetanggaan}

Hubungan ketetangaan biasanya dibentuk berdasarkan peta.

2. Jarak

Jarak antar suatu daerah dengan daerah lain dihitung berdasarkan informasi garis bujur dan garis lintangnya.

Dalam notasi matriks, matriks pembobot spasial dapat ditulis sebagai berikut:

$$
W=\left[\begin{array}{cccc}
W_{11} & W_{12} & \ldots & W_{1 n} \\
W_{21} & W_{22} & \ldots & W_{2 n} \\
\vdots & \vdots & \cdots & \vdots \\
W_{n 1} & W_{n 2} & \cdots & W_{n n}
\end{array}\right] \ldots \ldots(1)
$$

$W_{i j}=\left\{\begin{array}{lr}0, \text { jika } i \text { dan } \mathrm{j} \text { tidak bertetangga atau } i=j \\ 1, & \text { untuk yang bertetangga }\end{array}\right.$

Ketetanggaan dapat didefinisikan dalam beberapa cara [7], yaitu:

\section{- $\quad$ Persinggungan sisi (Rook Contiguity)}

Pada cara ini, daerah pengamatannya ditentukan berdasarkan sisi-sisi yang saling bersinggungan. Ilustrasinya dapat dilihat pada gambar 1, yaitu unit spasial A1, A2, A3, dan A4 merupakan tetangga dari unit spasial A, sedangkan Unit B1, B2, B3, B4 bukan merupakan tetangga dari Unit spasial A.

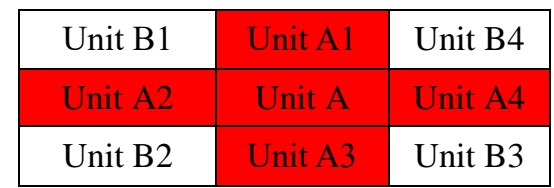

Gambar 1. Ketetanggaan Sisi

- $\quad$ Persinggungan sudut (Bishop Contiguity)

Pada cara ini, daerah pengamatannya ditentukan berdasarkan sudut-sudut yang saling bersinggungan dan sisi tidak diperhitungkan. Ilustrasinya dapat dilihat pada gambar 2 , yaitu unit spasial B1, B2, B3, dan B4 merupakan tetangga dari unit spasial A, sedangkan unit A1, A2, A3, A4 bukan tetangga unit spasial A. 


\begin{tabular}{|c|c|c|}
\hline Unit B1 & Unit A1 & Unit B4 \\
\hline Unit A2 & Unit A & Unit A4 \\
\hline Unit B2 & Unit A3 & Unit B3 \\
\hline
\end{tabular}

Gambar 2. Ketetanggaan Sudut

- Persinggungan sisi dan sudut (Queen contiquity)

Pada cara ini, daerah pengamatannya ditentukan berdasarkan sisi-sisi yang saling bersinggungan dan sudut juga diperhitungkan. Ilustrasinya dapat dilihat pada gambar 3 , yaitu unit spasial A1, A2, A3, dan A4 serta B1, B2, B3, dan B4 merupakan tetangga dari unit spasial A.

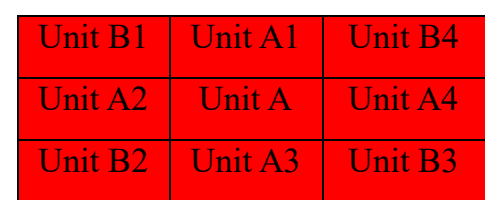

\section{Gambar 3. Ketetanggaan Sisi dan Sudut}

Dalam penelitian ini, matriks pembobot spasial dibentuk berdasarkan persinggungan sisi dan sudut (Queen contiquity). Sebagai ilustrasi, ada 6 wilayah seperti pada gambar 4 yang akan ditentukan matriks pembobot spasialnya.

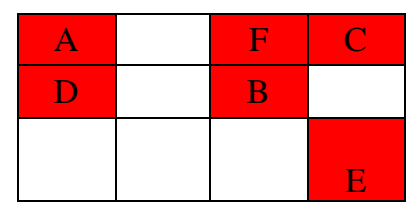

Gambar 4. Ilustrasi Contoh

Diperoleh matriks pembobot spasialnya adalah

$$
W=\left[\begin{array}{llllll}
0 & 0 & 0 & 1 & 0 & 0 \\
0 & 0 & 1 & 0 & 1 & 1 \\
0 & 1 & 0 & 0 & 0 & 1 \\
1 & 0 & 0 & 0 & 0 & 0 \\
0 & 1 & 0 & 0 & 0 & 0 \\
0 & 1 & 1 & 0 & 0 & 0
\end{array}\right] \ldots \ldots \ldots(2)
$$

\subsection{Uji Indeks Moran}

Uji indeks Moran merupakan salah satu uji yang digunakan untuk mengetahui ada tidaknya autokorelasi spasial. Autokorelasi spasial adalah taksiran dari korelasi antar nilai amatan yang berkaitan dengan lokasi spasial pada variabel yang sama. Nilai Indeks Moran dirumuskan sebagai berikut [8];

$I=\frac{n \sum_{i=1}^{n} \sum_{j=1}^{n} w_{i j}\left(x_{i}-\bar{x}\right)\left(x_{j}-\bar{x}\right)}{S_{0} \sum_{i=1}^{n}\left(x_{i}-\bar{x}\right)^{2}}$

dengan $S_{0}=\sum_{i=1}^{n} \sum_{j=1}^{n} w_{i j}$.

Indeks Moran perlu diuji signifikansinya dengan statistik uji

$Z(I)=\frac{I-E(I)}{\sqrt{\operatorname{var}(I)}}$

dengan

$E(I)=-\frac{1}{n-1}$

dan

$\operatorname{var}(I)=\frac{n^{2} s_{1}-n s_{2}+3 s_{0}^{2}}{\left(n^{2}-1\right) s_{0}^{2}}-[E(I)]^{2}$

Jika $\left|Z_{\text {hitung }}\right|>Z_{\frac{\alpha}{2}}$ maka disimpulkan ada autokorelasi parsial.

\subsection{Estimasi Parameter}

Dalam penelitian ini, digunakan metode kemungkinan maksimum untuk mengestimasi parameter-parameter yang dibutuhkan dalam model regresi spasial Durbin. Metode ini digunakan dengan tujuan memaksimumkan kejadian dari parameterparameter yang diestimasi.

\subsubsection{Model Regresi Spasial Durbin}

Secara umum, model regresi spasial Durbin adalah sebagai berikut [9] :

$$
\begin{array}{r}
y_{i}=\rho \sum_{j=1}^{n} w_{i j} y_{j}+\beta_{0 i}+\sum_{k=1}^{l} \beta_{1 k} x_{k i}+ \\
\sum_{k=1}^{l} \beta_{2 k} \sum_{j=1}^{n} W_{i j} x_{k j}+\varepsilon_{i} \quad \ldots \ldots \ldots . .
\end{array}
$$




\section{Keterangan:}

$$
\begin{aligned}
y_{i}= & \text { Nilai variabel dependen pada daerah ke-i } \\
y_{j}= & \text { Nilai variabel dependen pada daerah ke-j } \\
\rho= & \text { Nilai penduga parameter pengaruh spasial } \\
& \text { variabel dependen, yang menunjukkan } \\
& \text { tingkat pengaruh spasial dari suatu daerah } \\
& \text { terhadap daerah lain. } \\
w_{i j}= & \text { Nilai pembobot spasial yang menyatakan } \\
& \text { hubungan antara daerah i dan } \mathrm{j} \\
\beta_{0 i}= & \text { Nilai intersep } \\
\beta_{1 k}= & \text { Nilai parameter regresi tanpa pembobot } \\
& \text { spasial variabel independen ke-k } \\
\beta_{2 k}= & \text { Nilai parameter regresi dengan } \\
& \text { pembobot spasial variabel independen } \\
& \text { ke-k } \\
x_{k i}= & \text { Nilai variabel independen ke-k untuk } \\
& \text { daerah ke-i } \\
x_{k j}= & \text { Nilai variabel independen ke-k untuk } \\
& \text { daerah ke-j } \\
\varepsilon_{i}= & \text { Nilai galat pada daerah ke } i
\end{aligned}
$$

Dalam notasi matriks, persamaan (3), dapat ditulis menjadi:

$Y=\rho W Y+\beta_{0}+X \beta_{1}+W X \beta_{2}+\varepsilon$

Keterangan:

$\boldsymbol{Y}=$ Vektor nilai variabel dependen berukuran $n x 1$

$\boldsymbol{W}=$ Matriks pembobot spasial berukuran $n x n$

$\boldsymbol{\beta}_{\mathbf{0}}=$ Vektor intersep berukuran $n x 1$

$\boldsymbol{X}=$ Matriks variabel independen berukuran $n x k$

$\boldsymbol{\beta}_{\mathbf{1}}=$ Vektor parameter regresi tanpa mariks spasial terbobot berukuran $k x 1$

$\boldsymbol{\beta}_{\mathbf{2}}=$ Vektor parameter regresi dengan matriks spasial terbobot berukuran $k x 1$

$\boldsymbol{\varepsilon}=$ Vektor galat berukuran $n x 1$ $n=$ banyaknya daerah yang diamati

$k=$ banyaknya variabel independen

Untuk mempermudah perhitungan, persamaan (4) ditulis menjadi:

$Y=\rho W Y+Z \beta+\varepsilon$

Keterangan:

$\boldsymbol{Z}=$ Matriks berukuran $[n \mathrm{x}(2 k+1)]$, yang mana elemen-elemennya merupakan gabungan vektor satu, matriks $\boldsymbol{X}$, dan matriks $\boldsymbol{W} \boldsymbol{X}$ yaitu matriks yang merupakan hasil kali matriks $\boldsymbol{W}$ dan matriks $\boldsymbol{X}$. Secara matematis dapat ditulis sebagai berikut:

$$
\boldsymbol{Z}=\left[\begin{array}{lll}
\boldsymbol{A} & \boldsymbol{X} & \boldsymbol{W} \boldsymbol{X}
\end{array}\right]
$$

dengan A adalah vektor satu yaitu vektor yang seluruh elemennya bernilai satu yang berukuran $(n \times 1)$.

$\boldsymbol{\beta}=$ Vektor berukuran $(2 k+1) \mathrm{x} 1$,

$$
\text { dengan } \boldsymbol{\beta}=\left[\begin{array}{l}
\boldsymbol{\beta}_{\mathbf{0}} \\
\boldsymbol{\beta}_{\mathbf{1}} \\
\boldsymbol{\beta}_{\mathbf{2}}
\end{array}\right]
$$

\subsubsection{Metode Kemungkinan Maksimum}

Dalam metode kemungkinan maksimum, estimasi parameter dilakukan dengan memaksimumkan fungsi likelihoodnya. Fungsi likelihood pada model spasial Durbin adalah sebagai berikut [10]:

$$
\begin{aligned}
& \ln (L)=- \frac{n}{2} \ln (2 \pi)-\frac{n}{2} \ln \left(\sigma^{2}\right)+\ln |\boldsymbol{I}-\boldsymbol{\rho} \boldsymbol{W}|- \\
& \frac{1}{2 \sigma^{2}}[(\boldsymbol{I}-\boldsymbol{\rho} \boldsymbol{W}) \boldsymbol{Y}-\boldsymbol{Z} \boldsymbol{\beta}]^{\boldsymbol{t}}[(\boldsymbol{I}-\boldsymbol{\rho} \boldsymbol{W})- \\
&\boldsymbol{Z} \boldsymbol{\beta}] \ldots \ldots \ldots \ldots \ldots \ldots \ldots \ldots \ldots \ldots \ldots \ldots \ldots \ldots \ldots \ldots
\end{aligned}
$$

Selanjutnya, parameter-parameter yang akan diduga diperoleh dengan menurunkan persamaan (10) terhadap parameter yang akan diduga tersebut. Dalam analisis regresi spasial Durbin, parameter yang akan diduga adalah $\beta, \rho$. 
Secara metematis, ditulis:

$\frac{\partial(\ln (L))}{\partial \boldsymbol{\beta}}=0$

diperoleh:

$\widehat{\boldsymbol{\beta}}=\left(Z^{t} Z\right)^{-1} Z^{t}(I-\widehat{\rho} W) Y$

$\frac{\partial(\ln (L))}{\partial \rho}=0$

diperoleh:

$$
\begin{array}{r}
f(\rho)=c-\frac{n}{2} \ln \left(\left(\boldsymbol{e}_{\mathbf{0}}-\widehat{\boldsymbol{\rho}} \boldsymbol{e}_{\mathbf{1}}\right)^{\boldsymbol{t}}\left(\boldsymbol{e}_{\mathbf{0}}-\widehat{\boldsymbol{\rho}} \boldsymbol{e}_{\mathbf{1}}\right)\right)+ \\
\ln |\boldsymbol{I}-\boldsymbol{\rho} \boldsymbol{W}| \quad \ldots \ldots \ldots \ldots \ldots \ldots . . .(14)
\end{array}
$$

dengan,

$c=-\frac{n}{2} \ln (2 \pi)+\frac{n}{2} \ln (n)-\frac{n}{2}$

$e_{0}=Y-Z\left(Z^{t} Z\right)^{-1} Z^{t} Y$

$e_{1}=W Y-Z\left(Z^{t} Z\right)^{-1} Z^{t} W Y$

\subsection{Uji Kebaikan Model}

Kebaikan model regresi spasial Durbin yang terbentuk dapat dihitung dengan mencari nilai $\boldsymbol{R}^{2}$. Secara matematis, dirumuskan:

$$
R^{2}=1-\frac{\varepsilon^{t} \varepsilon}{(Y-\bar{Y})^{t}(Y-\bar{Y})}
$$

\subsection{Uji Signifikansi Parameter}

Uji signifikansi parameter merupakan uji yang digunakan untuk mengetahui variabelvariabel independen apa saja yang berpengaruh signifikan terhadap variabel dependen. Langkahlangkah uji signifikansi parameter adalah sebagai berikut [11];

- Menentukan hipotesis awal $\left(\boldsymbol{H}_{\mathbf{0}}\right)$

$\boldsymbol{H}_{\mathbf{0}}$ : tidak ada pengaruh signifikan

- Menentukan hipotesis akhir $\left(\boldsymbol{H}_{\mathbf{1}}\right)$

$\boldsymbol{H}_{\mathbf{1}}$ : ada pengaruh signifikan

- Menentukan Tingkat Signifikansi ( $\boldsymbol{\alpha})$, digunakan $\alpha=\mathbf{5} \%$
- Menghitung nilai statistik uji yang secara matematis dirumuskan:

$\boldsymbol{t}=\frac{\widehat{\boldsymbol{\beta}}_{i}}{\boldsymbol{s e}\left(\widehat{\boldsymbol{\beta}}_{i}\right)}$

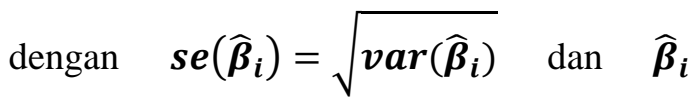
menyatakan nilai penduga parameter ke- $\boldsymbol{i}$.

- Menentukan keputusan yang akan diambil, berdasarkan kriteria sebagai berikut: $\boldsymbol{H}_{\mathbf{0}}$ ditolak apabila $|\boldsymbol{t}|>\boldsymbol{t}_{\frac{\alpha}{2}}(\boldsymbol{d} \boldsymbol{f})$ dengan, nilai $\boldsymbol{t}_{\frac{\alpha}{2}}(\boldsymbol{d} \boldsymbol{f})=\mathbf{2 . 0 4 2}$ ditentukan dengan melihat tabel $\boldsymbol{t}$, dengan $\boldsymbol{d} \boldsymbol{f}=\boldsymbol{n}-\boldsymbol{k}$

- Mengambil Kesimpulan

\section{HASIL DAN PEMBAHASAN}

Berdasarkan data yang digunakan, diperoleh hasil uji indeks Moran yang dapat diringkasi

\begin{tabular}{|c|c|c|c|}
\hline Variabel & $I$ & $Z(I)$ & Keterangan \\
\hline$Y$ & 0.301 & 2.9 & $\begin{array}{c}\text { Terdapat autokorelasi } \\
\text { spasial }\end{array}$ \\
\hline$X_{1}$ & 0.307 & 2.952 & $\begin{array}{c}\text { Terdapat autokorelasi } \\
\text { spasial }\end{array}$ \\
\hline$X_{2}$ & 0.108 & 1.207 & $\begin{array}{c}\text { Tidak terdapat } \\
\text { autokorelasi spasial }\end{array}$ \\
\hline$X_{3}$ & 0.207 & 2.072 & $\begin{array}{c}\text { Terdapat } \\
\text { autokorelasi spasial }\end{array}$ \\
\hline$X_{4}$ & 0.157 & 1.635 & $\begin{array}{c}\text { Tidak terdapat } \\
\text { autokorelasi spasial }\end{array}$ \\
\hline$X_{5}$ & 0.519 & 4.804 & $\begin{array}{c}\text { Terdapat } \\
\text { autokorelasi spasial }\end{array}$ \\
\hline$X_{6}$ & 0.238 & 2.345 & $\begin{array}{c}\text { Terdapat } \\
\text { autokorelasi spasial }\end{array}$ \\
\hline
\end{tabular}
dalam tabel sebagai berikut:

Tabel 2. Hasil Uji Indeks Moran

Sumber : analisis peneliti, 2019

Berdasarkan tabel 2, autokorelasi spasial hanya terdapat pada 5 variabel, yaitu variabel 
$\boldsymbol{Y}, \boldsymbol{X}_{\mathbf{1}}, \boldsymbol{X}_{3}, \boldsymbol{X}_{5}$, dan $\boldsymbol{X}_{\mathbf{6}}$. Oleh karena itu, hanya variabel-variabel ini saja yang dapat dimasukkan ke dalam model regresi spasial Durbin. Hal ini dikarenakan model regresi spasial Durbin adalah model yang melibatkan hubungan spasial yang terjadi baik pada variabel dependen maupun variabel independennya.

Selanjutnya, berdasarkan estimasi parameter dengan bantuan software $R$, dengan listing program sebagai berikut

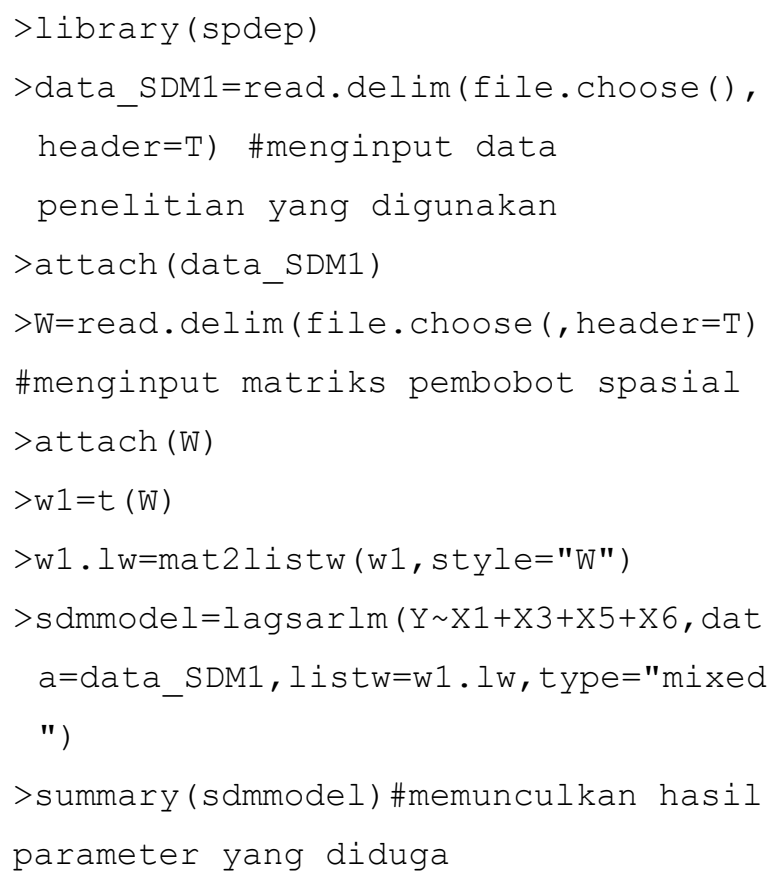

Diperoleh nilai penduga parameter seperti pada tabel 3

Tabel 3. Hasil Pendugaan Parameter

\begin{tabular}{cc}
\hline Parameter & Nilai Penduga \\
\hline$\hat{\beta}_{0}$ & 114.835905 \\
$\hat{\beta}_{11}$ & 0.068559 \\
$\hat{\beta}_{13}$ & -0.616375 \\
$\hat{\beta}_{15}$ & -1.116795 \\
$\hat{\beta}_{16}$ & -0.438258 \\
$\hat{\beta}_{21}$ & 0.364443 \\
$\hat{\beta}_{23}$ & -1.920527 \\
$\hat{\beta}_{25}$ & 0.938070 \\
$\hat{\beta}_{26}$ & -1.118218 \\
$\hat{\rho}$ & 0.03673 \\
\hline
\end{tabular}

Sumber : analisis peneliti, 2019
Dengan melihat tabel 3, dapat dibentuk model regresi spasial Durbin sebagai berikut $y_{i}=$

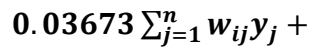

Untuk menguji seberapa baik model pada persamaan (17), dilakukan penghitungan nilai $\boldsymbol{R}^{2}$ sebagai berikut

$$
\begin{aligned}
\boldsymbol{R}^{2} & =1-\frac{\varepsilon^{t} \varepsilon}{(Y-\bar{Y})^{t}(Y-\bar{Y})} \\
& =\frac{183.0466}{580.1558} \\
& =0.6844872 \\
& =68.4 \%
\end{aligned}
$$

Nilai $\boldsymbol{R}^{\mathbf{2}}$ sebesar $\mathbf{6 8 . 4} \%$ menunjukkan seberapa baik model (17) dapat menjelaskan persentase penduduk miskin di Jawa Tengah pada tahun 2017 melalui variabel-variabel independen yang digunakan sedangkan sisanya sebesar 31.6\% dapat dijelaskan oleh variabelvariabel lain yang berhubungan dengan persentase penduduk miskin yang tidak dimasukkan ke dalam model.

Langkah selanjutnya adalah melakukan uji signifikansi parameter untuk mengetahui faktorfaktor apa saja yang berpengaruh signifikan terhadap persentase penduduk miskin di Jawa Tengah. Secara ringkas, hasil uji signifikansi parameter ditampilkan dalam tabel 4. 
Tabel 4. Hasil Uji Signifikani Parameter

\begin{tabular}{ccc}
\hline Parameter & Nilai $|t|$ & Keterangan \\
\hline$\beta_{11}$ & 0.97775 & Tidak signifikan \\
$\beta_{13}$ & 0.5001 & Tidak signifikan \\
$\beta_{15}$ & 2.37356 & Signifikan \\
$\beta_{16}$ & 2.54 & Signifikan \\
$\beta_{21}$ & 2.156327 & Signifikan \\
$\beta_{23}$ & 0.65515 & Tidak signifikan \\
$\beta_{25}$ & 1.3278 & Tidak signifikan \\
$\beta_{26}$ & 2.349 & Signifikan \\
\hline
\end{tabular}

Sumber : analisis peneliti, 2019

Berdasarkan tabel 4, parameter yang berpengaruh signifikan adalah $\beta_{15}, \beta_{16}, \beta_{21}$, dan $\beta_{26}$. Parameter $\beta_{15}$ menyatakan besarnya koefisien variabel $X_{5}$ tanpa pembobot. Parameter $\beta_{16}$ menyatakan besarnya koefisien variabel $X_{6}$ tanpa pembobot. Parameter $\beta_{21}$ menyatakan besarnya koefisien variabel $X_{1}$ dengan pembobot. Parameter $\beta_{26}$ menyatakan besarnya koefisien variabel $X_{6}$ dengan pembobot. Hal ini dapat diinterpretasikan bahwa ketika variabel lain dianggap konstan, jika usia harapan hidup $\left(X_{5}\right)$ naik 1 tahun maka persentase penduduk miskin turun sebesar nilai $\beta_{15}$ yaitu 1.116795 persen. Selanjutnya jika indeks pembangunan manusia $\left(X_{6}\right)$ naik 1 satuan maka persentase penduduk miskin turun sebesar nilai $\beta_{16}$ yaitu 0.438258 persen. Berdasarkan tabel 4 , parameter $\beta_{21}$ juga signifikan. Hal ini menunjukkan bahwa daerah yang nilai angka partisipasi sekolah usia 16-18 tahunnya tinggi bertetangga dengan daerah yang nilai angka partisipasi sekolah usia 16-18 tahunnya tinggi juga. Begitupun sebaliknya, daerah yang nilai angka partisipasi sekolah usia 16-18 tahunnya rendah bertetangga dengan daerah yang nilai angka partisipasi sekolah usia 16-18 tahunnya rendah juga. Parameter $\beta_{26}$ juga signifikan menunjukkan bahwa daerah yang indeks pembangunan manusianya tinggi bertetangga dengan daerah yang indeks pembangunan manusianya tinggi juga. Begitupun sebaliknya, daerah yang indeks pembangunan manusianya rendah bertetangga dengan daerah yang indeks pembangunan manusianya rendah juga.

\section{KESIMPULAN}

Kesimpulan yang diperoleh dari penelitian ini adalah

1) Model regresi spasial Durbin yang terbentuk mampu menjelaskan masalah persentase penduduk miskin sebesar $68.4 \%$.

2) Faktor-faktor yang berpengaruh signifikan terhadap persentase penduduk miskin di Jawa Tengah pada tahun 2017 adalah usia harapan hidup saat lahir dan indeks pembangunan manusia.

3) Usia harapan hidup saat lahir dan indeks pembangunan manusia berbanding terbalik dengan persentase penduduk miskin. Hal ini berarti penurunan persentase penduduk miskin di Jawa Tengah dapat dilakukan dengan meningkatkan usia harapan hidup saat lahir dan indeks pembangunan manusianya.

4) Untuk penelitian selanjutnya variabelvariabel yang digunakan dalam penelitian dapat diperbanyak untuk memperoleh model yang lebih baik lagi. 


\section{DAFTAR PUSTAKA}

[1] A. Widarjono, Ekonometrika Pengantar dan Aplikasinya. Jakarta: Ekonosia, 2013

[2] R. Kurniawan, Y. Budi, Analisis Regresi: dasar dan penerapannya dengan $R$. Jakarta: Kencana, 2016.

[3] Schabenberger , Gotway, "Statistical Methods for Spatial Data Analysis”. 2005. Chapman \& Hall/CRC.

[4] BPS Provinsi Jawa Tengah, tersedia di https://jateng.bps.go.id/. [diakses pada tanggal 04-03-2019]

[5] M. Aldino, Analisis Kemiskinan di Jawa Tengah, 2018

[6] N. Oktaviani, Analisis regresi spasial pada data jumlah penduduk miskin provinsi lampung pada tahun 2017, 2018.

[7] L. Putu Safitri Pratiwi, I Gusti Ayu Made, M. susilawati, "Analisis Kemiskinan dengan Pendekatan Model Regresi Spasial Durbin," E-Jurnal Matematika, vol. 2, no. 3, hal. 1116, 2013.

[8] R. Kosfeld, "Spatial Econometrics". 2006.

[9] L. Anselin, Spatial Econometrics: Methods and models. Netherlands: Kluwer Academic Publisher, 1988.

[10] R. Bekti., R. Anita, Sutikno, "Maximum likelihood estimation for spatial durbin model" Journal of Mathematics and Statistics, vol. 9, no. 3, hal. 169-174, 2013

[11] D. Gujarati, Basic Econometrics 4th edition. New York: Mc. Graw-Hill, 2003. 